\title{
COMPARATIVE ANALYSIS OF SPATIAL PLANNING SYSTEMS AND POLICIES: CASE STUDY OF MONTENEGRO, REPUBLIC OF NORTH MACEDONIA AND REPUBLIC OF SERBIA
}

\author{
Branka Tošić $^{* 1}$, Zora Živanović ${ }^{*}$ \\ "University of Belgrade-Faculty of Geography, Belgrade
}

\begin{abstract}
The paper contains an analysis and assessment of the planning system of three countries, Montenegro, Republic of North Macedonia and Republic of Serbia, located in the area of Southeastern Europe and the Western Balkans. Comparative analysis of development of the planning system includes several aspects - the level of the presence of the strategic and legal approach to the planning documents, adhering to the principle of sustainable development with a developed system of the preservation of environment, the types of plans and planning competence at different territorial levels with an assessment of achieved decentralization and democratization, connection between the private and the public sector, land management. The issue of vertical and horizontal coordination, including territorial cooperation, the existence of monitoring and implementation of plans, the coherence of planned objectives and developments in the area, the degree of representation of theoretical methodology in planning documents, the classification of three countries into one of the four European planning systems, as well as other numerous problems and challenges for the future in planning and in the space of the three states are contained in this paper.
\end{abstract}

Keywords: planning systems, comparative analysis, sustainability, realization, problems.

1 Corresponding author: B. Tošić, University of Belgrade-Faculty of Geography, Belgrade e-mail: branka.tosic12@gmail.com 


\section{Introduction}

Through centuries, different natural, historical, political and economic circumstances are linked to geographical mosaic that affected to administrative division, the appearance of settlements, planning system and management in a part of Southeast Europe and the Western Balkan countries to which the three countries belong.

The break-up of the SFR of Yugoslavia in the 1990s brought about significant changes in the planning system of three newly born states, Serbia, Montenegro and North Macedonia, which are former members of the common state. The period of transition and the admission of market laws, major territorial and economic changes, national independence and the increasing influence of the European planning system have had an impact on all changes in planning systems that have taken place with varying intensity in those countries. We consider the comparison of these three countries as a great challenge, given the turbulent period that has passed in the nearly three decades. This period, accompanied by a civil war and partly by sanctions, brought them great political and economic instability, and left behind an inter-ethnic antagonism that is hard to overcome. These are the basic factors for which progress in the planning systems of these countries, mainly in the area of territorial cooperation, did not proceed at the expected pace, and it was accompanied by numerous problems, both newly born and inherited from the previous period.

Previous socialist system of urban planning and land management had to be transformed into market-oriented and democratic system. Although important steps have been taken in this respect, there is still a need for further adjustment of modern planning system in accordance with European standards and policies, since all three countries are oriented towards the European path. Therefore, a concern remains how to improve the existing institutional and organizational situation, that would be effected by at the very least, the majority of strategic goals, and thus gave support in the direction of strategic research and management in North Macedonia, Montenegro and Serbia.

In order to obtain an overview of all the activities in the area of the three countries, comparative planning dealing with the similarities and specifics of the area is used in order to facilitate cooperation, harmonization and coordination of activities. Similarities in planning are explained by belonging to the same former state, and specifics and differences arise from positions, spatial characteristics, degree of development, tradition, etc. 


\section{The heterogeneous landscape for spatial planning in Europe}

Spatial planning systems in European countries have been analyzed several times over the past decades. Each of the approaches encompassed EU member States.

For instance, division of states by Newman and Thornley in 1996 for the purpose of systematizing spatial panning is well-known. They classified European planning systems, depending on the historical and political circumstances in which they originated from the original legislative framework, in four basic groups: Anglo-Saxon, "Napoleonic-type", German and Scandinavian planning systems.

Another significant division of state spatial development policies is from the EU Compendium for spatial planning (1997). Given that the countries that were then members of the EU were processed in the Compendium, 15 of them were grouped into four groups: a comprehensive integral approach, a regional economic approach, an approach where management of the purpose of the land is most important and approach that is primarily based on urbanism.

The ESPON project 2.3.2 (2006) brought a new classification of spatial planning system, entitled "Governance of Territorial and Urban Policies from EU to Local Level". The classification cited in the 1997 Compendium is used (Gestel, Faludi, 2005) and in comparison with it, the same four types or manners of planning has been retained. New, eastern European countries were added to the EU countries, but also Norway and Switzerland as an addition. A more complex analysis gave some different results even for the countries that were taken into account in the previous classification, but the conclusion is that it is difficult to classify planning systems as countries differ in different aspects of their planning practices, so that each of them does not meet all the criteria set for each planning system. Hence, there is a small number of countries belonging to only one planning system, and there is a general trend - approaching a comprehensive integral approach (Trkulja, et al. 2012). European classifications lack South Slavic "family" which had a far more elastic system than a rigid centralist system, so it differs from eastern European countries and cannot be classified with them in the same system (Pajović, 2006).

\section{Spatial planning in North Macedonia}

North Macedonia has an area of $25,713 \mathrm{~km}^{2}$ and it has about 2 million inhabitants. The capital is Skopje with about half a million inhabitants. The territory of the state comprises 8 statistical regions and 80 municipalities at the level of NUTS 4 and 5, 10 municipalities belong to the City of Skoplje (Vujošević, 2001). 
The planning of N. Macedonia includes several periods: early and middleaged planning, from the end of the $18^{\text {th }}$ century to the First World War, between the First World War and World War II, socialist planning in the second half of the $20^{\text {th }}$ century and planning after the fall of communism since the 1990s. The new spatial planning system in N. Macedonia is still being developed. Its goal is to implement the idea that planning institutions can operate at the local level, in the central government and as private organizations or parastatal bodies. Spatial planning of N. Macedonia tends to be of multidisciplinary type, with direct and indirect involvement of various individuals and institutions (Cavrić, Pavlović, 2015).

Types of plans. According to the Law on Spatial and Urban Planning (SVRM, 2005), the planning instruments for the territory of Macedonia are spatial and urban plans at the national, regional and local level. They are adopted for a period of 10 years, except for a national plan (15 years) and a detailed urban plan (5 years):

\section{Spatial plans}

1. National level

Spatial plan of the Republic of Macedonia (Spatial Plan Strategy of a Republic), adopted in 2004, is a strategic, but also a legal document and general basis for the spatial development and development of N. Macedonia. It prescribes the goals of the state and measures of spacious for the overall economic, social, ecological and cultural-historical development. The plan contains basic guidelines for the use of land, for the use of natural resources and protection measures. The plan was aiming to be harmonized with other national strategies related to sectoral and other various segments of development and protection of the area, and is implemented through plans to lower territorial areas.

Spatial plan for area of special interest for the Republic is adopted for areas of particular interest that require the special regime of use and protection development - national park or other protected area, reservoirs or water sources, the area for exploitation of mineral resources, infrastructural corridors, plants and systems of energy production, land reclamation systems and others.

The National sustainable development strategy (2008) is rather strategic than legal - planning document. The strategy has brought a clear picture of the future development of the country. It encompasses economic, social and environmental dimensions of development by 2030. In addition to the national plan, it is the most important document of an integral approach in the development of the state.

\section{Regional level}

The spatial plan of the region is being prepared for the geographical, economic and functional entities defined in the Spatial Plan of the Republic. Three regional 
plans are set as priorities. Other regional plans are prepared as draft: Spatial regional plan for the Skopje region and the Polog region.

\section{Local level}

Spatial plan of the municipality/or city of Skopje and municipalities in Skopje defines objectives and measures of spatial and urban planning of municipalities, in accordance with the economic, social, ecological and cultural-historical development planned in the Spatial Plan of the Republic. Since the existing adopted municipal plans have been adopted by the end of the $20^{\text {th }}$ century, in Macedonia, a municipal plan that has been harmonized with the latest law and the last national spatial plan has not yet been adopted.

\section{Urban plans}

General (master) urban plan - for the cities and the City of Skopje includes: the purpose of the planned solutions, general and special conditions for the parameters of spatial development for the implementation of the plan, conditions for detailed spatial planning, measures for nature, cultural heritage and environment protection and others. The plan also contains rules for the construction and arrangement of space. (The devastating earthquake in Skopje in 1963 prompted the initiative of planned construction of the capital, and activities were carried out with the financial assistance of the former joint state).

Urban plan for a part of the city aims to detail the urban planning of the part of the city for at least 30 ha, as specified in the General Urban Plan.

A detailed urban plan determines the rules of construction and arrangement of plots, regulation, leveling, utilities construction. The plan is obligatory for all settlements and parts of the settlement if its construction is determined by the spatial and urban plan of the local self-government.

Urban development plan for the village has been adopted for the area of the village in the municipality of rural character. The plan also contains the rules of construction and arrangement of plots, regulation, leveling, utilities construction.

Urban plan out of settlements defines how to use uninhabited space, as well as the rules for building construction objects in that area. It is adopted for areas not covered by previous urban plans.

Management system in spatial planning and assessment of planning system. The state has two levels of planning and management competence - national and local. At the national level, competencies are carried out by the Ministry of Transport and Communications, the Ministry of Environment and Spatial Planning, and the Agency for Spatial Planning. When it comes to the local level, planning is the responsibility of local government or municipal council. The municipality, or the municipal administration of the urban planning department, is in charge of planning programs for the development of urban plans, which 
determine the boundaries and contents of the planning document. Planning legislation recognizes two types of plans - spatial and urban plans, which must be mutually consistent (Bjokdahl, 2005; Koželj, Stefanovska, 2012; Tsenkova, 2014).

Although the system of planning, derived from the socialist period, functioned top-down, the changes were made by strengthening the environmental awareness that the consequences of planned activities on the environment, or the environmental impact at lower territorial levels, must be monitored. A geographic information system in mountainous and less developed areas has not yet been established. GIS technology is in the process of introduction with the aim to reach information on the ownership of land and the manner of its use (Pulevska, 2013). Municipalities do not own land and cannot buy land for themselves. Expropriation of land is in favor of the state and only the state can dispose of land. The land purpose change is frequent and can be approved by the competent Ministry (Cavrić, Pavlović, 2015; ESPON - Compass, 2016; Global Competitiveness Report 2017-2018).

\section{Spatial planning in Montenegro}

The Republic of Montenegro has an area of $13,812 \mathrm{~km}^{2}$, and its population is about 622,000 . The capital is Podgorica with about 187,000 inhabitants. The state is divided into 20 municipalities and the City of Podgorica, as a separate administrative unit. The state is in the process of constituting three regions - coastal, central and northern.

Types of plans. At the end of 2017, the Law on Spatial Planning and Construction and construction of objects (ZPCG, 2017) was adopted, according to which the number of plans was reduced to two.

Spatial Plan of Montenegro is a strategic document and general basis for organization and planning of the national space in which the national goals and measures of spatial development are determined, in line with the overall economic, social, ecological and cultural - historical development of the country etc. It determines the guidelines for the preparation of the plan of general regulation of Montenegro and for all aspects of space protection. The plan is being adopted for a period of 20 years.

The General Regulatory Plan is a document which defines in more detail the objectives and measures of spatial and urban development of Montenegro, while respecting the specific needs arising from regional specificities, and elaborates the objectives of space planning and the rational use of space and costal area, in accordance with economic, ecological and cultural - historical development. The plan includes the northern, central and coastal region, as well as the area of 
national parks and territories protected by the UN. Plan determines the purpose of surface; conditions for arrangement, construction and use of space; corridors and capacities for infrastructure; the boundaries of the construction areas of settlements; the boundaries of isolated construction areas outside settlements; the space envisioned for the development of urban projects; the boundaries of the protected area, etc. The plan also contains rules of arrangement and building codes by zones; rules of subdivision; guidelines for urban rehabilitation; guidelines for the development of urban projects, etc. For the center of the local selfgovernment unit, the plan must contain a detailed urban solution, and for rural areas - based on the arrangement of rural areas. It is adopted for a period of 10 years.

In order to implement the General Regulatory Plan of Montenegro, the assembly of the local self-government unit adopts an urban project, on the proposal of the executive body of the local self-government unit. The design of the plans was taken over by the competent Ministry of Sustainable Development and Tourism. The existing national plan adopted by the end of the first decade of this century is valid until the end of the planning period, by 2020 .

Management system in spatial planning and assessment of planning system. Management system and spatial planning of Montenegro functions at the national level, since almost all competencies have been taken over by the Ministry of Sustainable Development and Tourism (with the Directorate for Planning). By adopting the new Law, the local level is only responsible for urban projects.

The planning system is centralized, municipalities lack resources, as well as capacities for independent decision-making. Public participation is insufficiently implemented, although legally prescribed by the new Law. When it comes to environmental protection, in 1991, Montenegro adopted the Declaration of Ecological State on the principles of sustainability. This led to the preparation of a strategic framework document the Guidelines for Development of Montenegro as an Ecological State in 2000 (Cavrić, Pavlović, 2015; ESPON - Compass, 2016).

\section{Spatial planning in Serbia}

Serbia is located in the area of $88,361 \mathrm{~km}^{2}$, and it has about $7.100,000$ inhabitants. The capital city is Belgrade, which in its administrative area covers about $1,700,000$ inhabitants. The state contains two autonomous provinces, five statistical regions (NUTS level 2) divided into 30 districts and 174 local units.

Legislation in planning. The main objective of the adoption of the Law on Planning and Construction from 2009 (ZPS, 2009) is related to a part of urban planning, in particular - for the legalization of illegally constructed buildings, 
and in particular to accelerate the process of obtaining construction permits, what was highlighted in reports of the World bank as one of the biggest problems in achieving better business conditions.

Amendments to the existing Law, 2014, continue to affect time reduction, simplifying procedures, but also reducing costs in obtaining building permits. Within the framework of spatial planning, this Amendment brought about an increase in the level of democracy (introduction of early public insight) in the process of planning and reduction of phases in the preparation of planning documents (the first phase - concept of the plan is abolished, so the drafting is limited to the draft plan). In 2018, amendments to the existing Law on Planning and Simplification were adopted.

Types of plans. The lawfully defined planning documents of Republic of Serbia are produced at the national, regional and local level (ZPI, 2009). All planning documents have been developed and adopted for a period of 10 years.

Spatial plans

1. National level:

The Spatial Plan of the Republic of Serbia has a strategic-development and general regulatory function, and it is adopted as a legal act. It contains basic goals and measures for planning the national space with planning guidelines at lower territorial levels.

2. Regional level:

Spatial plan of special-purpose area is a plan of national interest for the area with a special regime of organization, development, use and protection of the area (area with natural, cultural, historical or environmental value, with the possibility of exploitation of mineral resources; with the possibility of use of tourism potential, hydropower etc.).

The regional spatial plan is developed for larger spatial units of administrative, functional, geographical or statistical character, directed towards common goals and projects of regional development. Taking into account the specific needs arising from regional specifics, the plan elaborates the goals of spatial planning and determines the rational use of area in accordance with neighboring regions and municipalities.

\section{Local level:}

The spatial plan of the local self-government unit is adopted for the territory of the municipality/municipality with the status of the city, and determines guidelines for the development of activities and the purpose of the areas, as well as the conditions for sustainable and balanced development on the territory of the local self-government unit. 


\section{Urban plans}

The general urban plan is adopted as a strategic development plan, with general elements of spatial development for a populated area that has the status of a city.

The general regulation plan is adopted for a populated area which is the seat of a local self-government unit for the entire construction area, and/ or for other settlements in the territory of the local self-government.

A detailed regulation plan is made for parts of a populated area, the arrangement of informal (illegal) settlements, renewal of urban zones, infrastructure corridors and facilities and areas for which its creation is mandatory, determined by the previously adopted planning document.

Management system in spatial planning and assessment of planning system. Although the planning in Serbia is formally decentralized, with competences at national and local level, it still works without management at the regional level. At the national level, the Ministry of Civil Engineering, Transport and Infrastructure of Serbia defines the legal framework and evaluates the implementation of the law. It defines development policies and gives permits for the development of projects that are of national importance for the Republic of Serbia, while the Minister gives final approval of the plan. The state has the authority to supervise spatial planning activities at lower levels. The Ministry, in which the Republic Agency for Spatial Planning is integrated in 2014, has the role to determine the standards, implementation procedures, to order plans, to control their development and to provide technical assistance in the organizational sense.

So far, the regional level is only an instrument of central government implementation. Only two of the five regions (the City of Belgrade and the province of Vojvodina) have regional administrative bodies and legal competence for the implementation of spatial planning in their entire territory. At the local level, municipalities/cities have the right to organize spatial management and planning of their territories, except if the activities are of national importance (Danilović-Hristić, Stefanović, 2013; Golubovic-Matic, 2015; Ivanović, et al. 2015; ESPON - Compass, 2016).

\section{Comparative analysis and conclusions}

Thirty years ago, three countries North Macedonia, Montenegro and Serbia were republics of SFR Yugoslavia. As Yugoslavia was a decentralized country, each republic had its own law on spatial planning, institutions, planning documents and planning procedures. However, despite a certain degree of inde- 
pendence - planning systems within each republic mostly took place in a similar manner with many common elements.

After the dissolution of SFR Yugoslavia in the 1990s, all three countries are facing numerous economic and other difficulties, and do not manage to properly review the planning in the following period. There are still many obstacles in the current systems and practice of spatial and environmental planning which will represent a mix of old habits and substandard access, with only some changes according to the legislation in the EU and perceived good practice (Djordjević, Dabović, 2009).

Planning documents in all three states determine the organization, provided use of space, as well as measures and guidelines for the development, protection and improvement of the area. Planning documents must be mutually harmonized, based on the principle of vertical coordination, that is, plans of a lower territorial level must respect hierarchically higher plans. In addition, the plans must be in line with the adopted regulations in the field of environmental protection, infrastructural facilities, economy, energy, natural resources, as well as sectoral documents in the field of sports, tourism and other legal requirements.

In order to get an overview of all planning activities in the territory of the three countries, we use comparative planning to define uniform frameworks that allow harmonization of planning practices, offering standards and recommendations for future development.

In planning systems in N. Macedonia and Serbia, spatial and urban plans are being drafted, while in Montenegro these plans are "replaced" by the General Regulatory Plan. Urbanistic aspect is equally represented and implemented through several plans that include construction and regulation rules with complete regulatory conditions in the planning of public areas and other plots. At the local level, N. Macedonia and Serbia, besides urban plans, also work on spatial plans and plans at the regional level, while the aforementioned plan of Montenegro includes the planning of three regional levels, protected areas, areas with a special purpose, but also defines construction rules for uninhabited areas; for the center of local self-government unit's plan must contain a detailed urbanistic solution, and for rural areas - bases of organization of rural areas, with guidance for urban projects. The oddity is that the plans in Montenegro are being developed by the competent Ministry for Sustainable Development and Tourism!

When it comes to the development of plans at the regional level, this process has been present in N. Macedonia and Serbia until now, but it is also constituted in Montenegro in the new Law (ZPCG, 2017). Plans related to the wider administrative area of Skopje and Belgrade are also included in this type of plans. N. Macedonia and Serbia have special purpose plans for specific regional spheres of national importance, and in Montenegro, with new legal requirements, these areas are planned within the framework of the General Regulation Plan. 
The national level in all three countries is represented in the form plans that have legal grounds. Although national plans are strategically oriented, their objectives, measures and principles are adopted by the legislative authorities of the states and represent guidelines for lower-level plans. Since national plans become legal acts, this mostly differs from the strategic national and directing documents of most European countries. National plans in all three countries are valid until 2020. Instrument for monitoring and implementation, also exist in $\mathrm{N}$. Macedonia, at the national, and in Serbia, at the national and regional level, while local plans are directly implemented on the basis of defined rules of construction and arrangement.

The operational approach with land use, regulation and urban zoning in the planning system in all three countries somewhat dominates over the strategic approach. Strategic principles can be identified in national planning document, and in some segments in regional spatial plans.

When it comes to planning competences, there are differences between countries. There is no regional jurisdiction in planning and regional development. N. Macedonia is characterized by a still centralized, i.e. top-down approach, where municipalities have no conditions for a comprehensive planning process. In Serbia, the degree of centralization is reduced to almost absolute jurisdiction of local self-government, as well as the possibility of the province and the City of Belgrade to decide on plans in their territory. Montenegro has again centralized the planning system by adopting laws that the competent Ministry is developing and making all decisions on plans. The principle of decentralization in planning and management generally fails in each of the countries.

Vertical coordination in the planning of countries is represented by the adoption of goals and measures from higher-order plans, but not with the cooperation of institutions, since they do not exist at all levels. Horizontal cooperation is supported, both by law and by European guidelines. When it comes to sectoral strategies and planning documents, cooperation is at a low level. On the other hand, cooperation means coordination at local and regional territorial levels within countries, and it is recognized in the form of cross-border, transnational, interregional and Euro-regional cooperation with other countries. Cooperation, however, has not achieved a desirable level, its progress is slow and has no clear orientation, since it largely depends on local initiatives and public awareness of all available opportunities. In the case of the three countries, but having in mind that each of them is formally decisive to join the EU, it is often the case that those apply European and other standards that have come from the outside without the participation of home countries. These standards, however, may, but need not to, be consistent with the circumstances of the country (Tsenkova, Nedović-Budić, 2006). 
Entrepreneurial initiatives and private investment are gaining in importance, but their goals are often contrary to public interests. The public sector still plays a decisive role in the planning system and implementation of plans. Planning systems are assessed as complex and incompatible with EU standards, especially with regard to the principles and instruments of integrated urban development (ESPON Compass, 2016).

The principle of sustainable development is supported in all planning documents. Although it is still in great contradiction with the implementation in practice, the environmental aspect with all elements of protection is represented in the planning of all countries. In Montenegro, it arises from the fact that the Declaration of Ecological State has been adopted and, in Serbia and N. Macedonia, there are additional planning documents that are adopted as Strategic Assessment of impact on Environment (Serbia) or Environmental Protection Program (N. Macedonia). In addition to ecological care and consideration of the possibilities of economic development, planning systems pay attention to social issues - equality of all groups of population, social inclusion, etc.

Problems in all three countries can be identified according to the assessment, as there are inefficient implementation mechanisms, lack of prevention from natural disasters, lack of transparency in the planning process, land market disturbances, underdeveloped national land use policy, political instability, manipulation and corruption. Even though new 'Agency for the management' and similar organizations are introduced, the systems in the states have continued to deal with key development issues. Legitimacy of planning is relatively low, and planning practice represents a mixture of elements from different 'models' (Vujošević, Maričić, 2012).

The planning goals are often unrealistic and are not in line with the degree of implementation of plans. Although plans are not burdened with theoretical methodology, they do not have a high degree of realization, which is not always the result of unforeseen changes in the area. One of the causes is insufficient cooperation with institutions that are in charge of the implementation of priority planning measures (case of Serbia).

A major problem in planning of countries is informal settlements, since almost all cities, the coastal belt in Montenegro, and other areas in the countries have been illegally built. Uncontrolled and stressful urban growth is becoming one of the most important issues - how to maintain quality and how to manage future urban development using control and all the necessary instruments. A common problem relates to the underdeveloped information system in planning, as well as the further low level of participation. Participation of citizens in planning is legally supported, but in practice there is insufficient transparency and poor information of citizens. Public insights are taking place after the adop- 
tion of plans, and in Serbia and Montenegro at the beginning of its development, but not in either of these countries during the whole process of drafting the plan (ESPON - Compass, 2016).

According to the representation of planning at all territorial levels, it can be concluded that planning in Serbia and N. Macedonia belongs to an integral planning system, with, though, insufficiently developed by other instruments that characterize this system (all relevant sectors having an impact on the area are insufficiently included; insufficient coordination between the public and the private sector, there is no developed vertical hierarchy of institutions, since the regional level of competencies is lacking, except at the provincial level in Serbia and at the level of capitols; lack of horizontal cooperation, etc.). The abolition of numerous plans in Montenegro in 2017 reduces the planning to a combination of spatial, regional, special purpose plans and construction of non-uninhabited areas, on one hand, with urban planning with dominant zoning and land use, with regulatory conditions, on the other hand, within the framework of sole general regulation plan. The great difference in Montenegro with regard to territorial competencies in these planning systems in relation to other European countries relates to re-centralization, as the competent Ministry took over the drafting and adoption of a national plan and general regulation plan (Trkulja, Dabović, 2017).

In the future, planning in country should focus on further respect of the principles of sustainable development, the achievement of a higher level of decentralization in governance, and providing technical assistance in planning with the support of the local level. At the regional level, jurisdiction should be introduced, and it needs to be supported at the local level, as it contributes to democratization in planning, as well as to the preservation of local identity and makes it more independent from external influences. Greater transparency in the planning process will involve all parties during the entire planning period. It is necessary to simplify the process of adopting plans (N. Macedonia), simplifying and shortening the process of obtaining building permits (Serbia), as well as overcoming illegal planning activities (especially in Montenegro). It is essential to influence the transfer of ownership of land from the central to the local level, and local authorities should be provided with discretionary rights that can be achieved when it comes to establishing local development priorities (N. Macedonia). The planning system in all three countries should act in many activities to prevent the change in land use, since the principle of reducing the transformation of the land, especially agricultural land to construction land, should be respected. Inspection services should be more efficient, and criteria and indicators in the implementation of plans should be harmonized with the EU. It is necessary to comply with environmental legal provisions in all countries, which are also defined at the European level, with the reduction of corrup- 
tion in all areas of planning. All aspects of territorial and cross-border cooperation should be developed with better training of citizens. A large degree of unbalanced territorial development can be overcome by polycentric development (demetropolisation, primarily Belgrade and Skopje, as well as the development of central and northern regions of Montenegro) with the activation of smaller centers and nuclei of rural development. Depopulation problems should be resolved by national population policies, and a lack of funds, at least to a certain extent can be overcome by defining development projects with financing from European funds designated for the development of the Western Balkans.

Acknowledgment: This paper is a result of research into two projects, under the No: 176017 and 47006 financed by the Serbian Ministry of Education, Science and Technological Development.

\section{References}

Bjokdahl, A. (2005). Norm-maker and Norm-taker: Exploring the Normative Influence of the EU in Macedonia. European Foreign Affairs Review, 10, 257-278.

Cavrić. B., \& Pavlović D. (2015). ISOCARP International Manual of Planning Practice. Edit. Judith Ryser and Teresa Franchini, London and Madrid.

Danilović-Hristić, N., \& Stefanović, N. (2013) The role of public insight in urban planning process: increasing efficiency and effectiveness. Spatium, 30, 33-39.

Djordjević, D., \& Dabović,T. (2009). System of spatial planning of Serbia, Dela 31, 143-157.

ESPON - Compass (2016). Comparative Analysis of Territorial Governance and Spatial Planning Systems in Europe. Applied Research 2016-18. Inception Report, Version 01/11/2016.

ESPON Project 2.3.2. (2006). Co-financed by the European Community through the Interreg III ESPON Programme. Governance of Territorial and Urban. Policies From EU to Local Level. Third interim report.

EU Comendium of spatial planning systems and policies (1997). Regional development sudies, EU, Regional policy and cohesion, European Commission.

Gestel, V. T., \& Faludi, A. (2005). Towards a European Territorial Cohesion Assessment Network, A Bright Future for ESPON Special Issue of Town Planning Review, 76, 81-92.

Global Competitiveness Report (2017-2018). Klaus Schwab,World Economic Forum.

Golubović-Matić, D. (2015). ISOCARP International Manual of Planning Practice. Edit. Judith Ryser and Teresa Franchini, London and Madrid. 
Ivanović, S., Radosavljević, Z., Rajić, E., Filipović, D., Dreger, Š., Tielman, G., Mueller, H. \& Čolić, R. (2015). Guide to Strategic Environmental Assessment in Urban Planning. Belgrade: CSTAMPA.

Koželj, J., \& Stefanovska, J. (2012). Urban planning and transitional development issues: The case of Skopje, Macedonia. Urbani izziv 23, 91-100.

Newman, P., \& Thornley, A. (1996). Urban Planning in Europe: international competition, national systems and planning projects. Psychology Press, p. 291.

Pajović, D. (2006, August, 17). Urbanistički zakoni južnoslovenskih zemalja - BiH, Crna Gora, Hrvatska, Makedonija, Slovenija, Srbija - Prikaz važećih zakona. E-kapija. Retrived from https://www.ekapija.com/news/65785/

Pulevska, B. (2013). Strategic Concept - The Role of Spatial and urban Planning for Better Climate Change Management - Republic of Macedonia, Ministry of Environment and Physical Planning, Skopje.

SVRM (2005). Služben vesnik na Republika Makedonija. Zakon za prostorno $i$ urbanisticko planiranje. Br. 07-2510/1.

Trkulja, S., Tošić, B., \& Živanović, Z. (2012). Serbian Spatial Planning among Styles of Spatial Planning in Europe. European Planning Studies 20, 1729-1746.

Trkulja, S., \& Dabović, T. (2017, October). Common Territorial Cooperation Guidelines in the Western Balkans. Paper presented at the scientific meeting Territorial governance and spatial planning in the Western Balkan Region, Torino.

Tsenkova, S., \& Nedović-Budić, Z. (2006). The urban mosaic of Post-socialist Europe. Liepzig: Physica-Verlag.

Tsenkova, S. (2014). Planning trajectories in post-socialist cities: patterns of divergence and change. Urban Research \& Practice, 7, 278-301.

Vujošević, M. (2001). Geography lost and found - Integrating six Balkan countries through Co-projects ESTIA and OSPE, Early experience, Institute of Architecture and Urban \& Spatial Planning of Serbia, Belgrade.

Vujošević, M., \& Maričić, T. (2012). The Conundrum of a State Spatial Plan Implementation: The Spatial Plan of the Republic of Serbia (2010) in Aesop 26th Annual Congress, Ankara.

ZPS (2009). Zakon o planiranju i izgradnji Republike Srbije ("Sl. glasnik RS", br. 72/2009, 81/2009 - ispr., 132/2014; 83/2018, 31/2019 i 37/2019).

ZPCG (2017). Zakon o planiranju prostora i izgradnji objekata Crne Gore ("Sl. list CG", br. 64/2017, 44/2018, 63/2018 i 11/2019). 